\title{
PUBLIC CONCERNS AND \\ CHOICES REGARDING NUCLEAR WASTE REPOSITORIES
}

\author{
William L. Rankin \\ Stanley M. Nealey
}

JUNE 1981

Work performed under contract DE-AC06-76RLO-1830

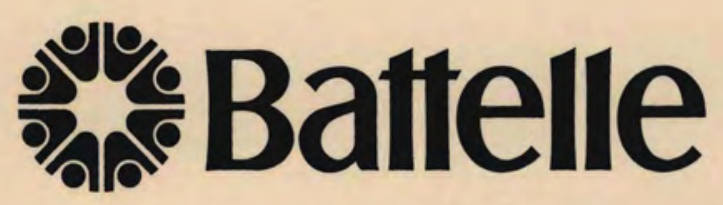

Human Affairs Research Centers

4000 N.E. 41st Street $\bullet$ Seattle, Washington 98105 


\section{Legal Notice}

This report was prepared by Battelle as an account of sponsored research activities. Neither Sponsor nor Battelle nor any person acting on behalf of either: (a) Makes any warranty or representation. express or implied, with respect to the accuracy, completeness, or usefulness of the information contained in this report or that the use of any information, apparatus, process, or composition disclosed in this report may not infringe privately owned rights; or (b) Assumes any liabilities with respect to the use of, or for damages resulting from the use of, any information, apparatus, process, or composition disclosed in this report. 
PNL -3797

BHARC $-411 / 81 / 003$

UC-70

\section{PUBLIC CONCERNS AND CHOICES REGARDING NUCLEAR WASTE REPOSITORIES}

Topical Report

William L. Rankin

Stanley M. Nealey

June $\cdot 1981$

\section{Prepared for the Waste Management Systems Studies Program of the Pacific Northwest Laboratory of the U.S. Department of Energy under contract DE-AC06-76RLO-1830}

Battelle Memorial Institute Human Affairs Research Centers Social Change Study Center Energy and Environment Program Seattle, Washington 98105 
Survey research on nuclear power issues conducted in the late $1970 \mathrm{~s}$ has determined that nuclear was te management is now considered to be one of the most important nuclear power issues both by the U.S. public and by key leadership groups. The purpose of this research was to determine the importance placed on specific issues associated with high-level waste disposal. In addition, policy option choices were asked regarding the siting of both low-level and high-level nuclear waste repositories.

A purposive sampling strategy was used to select six groups of respondents. Nuclear Engineers, Chemical Engineers, and Science Writers were randomly selected from the membership lists of national professional organizations. Environmentalists were randomly selected from the membership lists of two regional and one national environmental organization. Six General Communities were purposively sampled from six geographic areas of the U.S., and respondents were randomly selected from the telephone directories of these six cities. Finally, six Hazardous Facility Communities were purposively sampled, and residents were randomly selected from the telephone directories of these communities.

A four-wave, mail-out technique was used for data collection. Response rates ranged from $40 \%$ to $50 \%$ for Science Writers, Genera? Communities, and Hazardous Facility Communities; and from $75 \%$ to $85 \%$ for the Nuclear Engineers, Chemical Engineers, and Environmentalists. In the remainder of this section, a summary of the importance placed on specific high-level waste repository issues is presented first, followed by a summary of the policy option preferences. 
Averaged across the six respondent groups, the leakage of liquid

wastes from storage tanks was seen as the most important high-level waste issue. All groups ranked it first or second in importance. There was also general agreement that the issue regarding water entering the final repository and carrying radioactive wastes away was second in importance. Overall, the third most important issue was the corrosion of the metal containers used in the high-level waste repository. However, the General Communities, Hazardous Facility Communities, and the Environmentalists all placed much more importance on this issue than did the Nuclear Engineers, who ranked it sixth.

There was general agreement among groups that the fourth most important issue was reducing safety to cut costs. The fifth most important issue was radioactive waste transportation accidents. However, there were large differences among groups regarding the importance of transportation accidents. While the Nuclear Engineers ranked it second, the Environmentalists, the General Communities, and the Hazardous Facility Communities ranked the issue sixth or seventh. Overall, the issues ranked sixth and seventh were, respectively, workers' safety and earthquakes damaging the repository and releasing radioactivity.

The eighth most important issue, overall, was regarding explosions in the repository from too much radioactivity, which is something that is not possible. Except for the General Communities, all respondent groups ranked this issue eighth through tenth. The General Communities, exhibiting a general concern about nuclear explosions, ranked this issue fourth in importance. There was general agreement across all six respondent groups that the two least important issues involved people 
accidentally digging into the site and the issue that the repository might cost too much and would therefore raise electricity bills.

These findings have important implications for waste management information programs and for public meetings held with regard to repository siting issues. First, the main public concern is with regard to the leakage of 1 iquid wastes from storage tanks. Thus, information about the fact that DOE no longer stores liquid wastes in single wall tanks ( 1 iquid wastes are now stored only in double wall tanks) from which the leaks occurred should be disseminated more widely. Second, the high level of concern about water entering the repository and carrying away wastes should receive major attention in information programs and public meetings. A related issue, the corrosion of the metal containers in the repository, should also be covered by the programs. Since these containers are, ultimately, expected to corrode, this issue may take on greater salience as the siting program comes closer to reality. Also, the respondent groups indicated little concern about repositories costing too much, but showed a lot of concern that costs might be cut on the repository, thereby reducing safety. Since this will not be the case because the repositories will be required to meet stringent requirements that are not based on cost, the cost aspect of the repositories should be explained, especially at public meetings. Finally, these data indicate that the concerns of nuclear waste technologists and other public groups do not always overlap. Thus, it is important that those technologists who work in the information programs and those who attend the public meetings be aware of these differences, so that the public concerns are addressed. 
The respondent groups were also asked their preferences regarding options for siting low-level and high-level waste repositories. Specifically, they were asked for each type of repository, whether each state should have its own low-level (high-level) repository, whether six to ten sites should be selected on a regional basis, or whether two or three sites should be selected nationally.

Regarding low-level repositories, Chemical Engineers, Nuclear Engineers, and Science Writers gave plurality support or slight majority support to the regional siting option. The second preference for these three groups was the state siting option. However, the General Communities and the Hazardous Facility Communities gave plurality preference to the state siting option and second preference to the national siting option. The Environmentalists did not show a strong preference for any of the three options--each option was chosen $20 \%$ to $30 \%$ of the time as the most preferred option.

Slightly more consensus was shown regarding the preferred siting option for high-level waste repositories. All groups gave plurality support or majority support to the national siting option. However, the second preference of Nuclear Engineers, Chemical Engineers, and Science Writers was the regional siting option, while the second preference for the General Communities and the Hazardous Facility Communities was the state siting option. Although the plurality of the Environmentalists selected the national siting option, this group again seemed not to favor any of the siting options--over one-third of the Environmentalists offered a different suggestion regarding the siting of high-level waste repositories. 
These groups were not asked their policy preferences as a "vote" as to which policy should be implemented. Rather, they were asked their preferences in order to determine how much opposition there might be to the policies that are now being implemented. The present policy for high-level wastes is the national siting option. The present policy for low-level wastes is that each state is responsible for its own wastes, but the states have been given the legal authority and encouragement to enter into regional pacts. Thus, there are two important implications of these survey findings with regard to the present waste management policies.

First, the respondents from the more general publics had a tendency to believe that each state should have facilities for its own nuclear wastes. This was especially the case for low-level wastes, and a large minority of these respondents felt that states should take care of their own high-level wastes. Thus, the information programs and officials at public meetings should be prepared to explain why it is not preferable for each state to take care of its own high-level wastes and why the regional siting option may be preferable for the low-level wastes.

Second, environmentalist groups, as a whole, did not strongly support any of the siting options for either type of waste. Coupled with their concerns over high-level repositories and the fact that many of these respondents do not separate the nuclear waste management issue from the more general issue of nuclear power, environmentalists are likely to oppose any specific repository siting proposal. 
EXECUTIVE SUMMARY. . . . . . . . . . . . . . . . . . . . i i

TABLE OF CONTENTS. . . . . . . . . . . . . . . . . . vii LIST OF TABLES ....................... . viii INTRODUCTION . . . . . . . . . . . . . . . . . . . 1 RESPONDENTS. . . . . . . . . . . . . . . . . . 3

Sampling . . . . . . . . . . . . . . . . . . 3

Questionnaire Mailing Procedures . . . . . . . . . . 6

Response Rates . . . . . . . . . . . . . . . . . 7

PUBLIC CONCERNS ABOUT HIGH-LEVEL WASTE REPOSITORY ISSUES . . . . . . 10

Introduction . . . . . . . . . . . . . . . . . 10

"Don't Know" Responses . . . . . . . . . . . . . . . . . 10

Issue Importance . . . . . . . . . . . . . . . . 12

Summary. . . . . . . . . . . . . . . . . . 17

PUBLIC PREFERENCES FOR REPOSITORY SITING OPTIONS . . . . . . . . . 21

Introduction . . . . . . . . . . . . . . . 21

Low-Level Waste Repositories . . . . . . . . . . . . . 21

High-Level Waste Repositories. . . . . . . . . . . . 24

SUMMARY AND DISCUSSION . . . . . . . . . . . . . . . . . 28

REFERENCES ........................... . . . . 33 
TABLE 1. Response Rates for Al1 Groups............... 9

TABLE 2. Average Importance of Waste Management

Issues Compared to Each Other. . . . . . . . . . . . . . 11

TABLE 3. Percentage of Respondents who Prefer a Given Siting Policy for Low-Level Waste Repositories as a Function of Group Membership . . . . . . . . . . 22

TABLE 4. Percentage of Respondents who Prefer a Given Siting Policy for High-Level Waste Repositories as a Function of Group Membership . . . . . . . . . 


\section{INTRODUCTION}

Public concern over nuclear waste management has grown through the 1970 s until nuclear waste management has replaced reactor safety concerns as the major perceived problem regarding nuclear power (Melber et al., 1977; Rankin and Nealey, 1978). Even public opinion surveys conducted during the Three Mile Island accident in 1979 found that the public was more concerned about waste management than reactor safety and the escape of radioactivity into the atmosphere (Melber et al., 1979; Rankin and Melber, 1980).

However, none of the surveys has determined what specific concerns the public has about waste management. Volunteered responses to questions about waste management have only determined that some of the public thinks that wastes are "dangerous," "poisonous," or "deadly." While these general fears do reflect concern over waste management, they are not specific enough for scientists and engineers involved in nuclear waste management to determine whether their technical programs are being responsive to various "publics." These publics include the general public and other involved publics, such as nuclear scientists and environmentalists. One major objective of this research was to determine more specifically what it is about high-level waste repositories that concerns these publics.

Public concerns over waste management, of course, influence public attitudes about the siting of waste repositories--both high-level and lowlevel repositories. While the siting of a high-level repository is more controversial than the siting of a low-level repository, the siting of low-level repositories is not without its difficulties. Of course, very 
few people are interested in living near any potentially hazardous facility, including a waste management facility. However, the need for such facilities is clear, since both low-level and high-level nuclear wastes continue to be produced in the U.S. for medical, industrial, national defense, and electrical power production purposes. Thus, a second objective of this research was to survey general public attitudes about how low-level and high-level nuclear waste disposal facilities should be sited in order to be most equitable to everyone involved. 
RESPONDENTS

Sampling

A purposive or "judgmental" sampling strategy (Babbie, 1973) was used in the present study. Purposive sampling, also known as "theoretical sampling" (Glaser \& Strauss, 1968), "scope sampling" (Willer, 1967) or "sampling of publics" (Blumer, 1948), is characterized by the sampling of the memberships of established groups. The selection of the established groups is guided by the research questions being studied: those groups are selected that would most efficiently provide the information required. Purposive sampling is far more efficient than probability sampling, which involves drawing a well-defined sample from a well-defined population. The degree to which a sample is representative of a population is statistically assured with probability sampling but not with purposive sampling. Since it is not a purpose of the present study to make statements about particular populations, the assured representativeness of population sampling is not required. This study is designed to explore comparisons among established groups, and purposive sampling allows those comparisons to be made efficiently.

Groups of potential respondents were selected on the bas is of the interests of their membership in risks associated with industrial facilities. Six groups were selected:

1. Nuclear Engineers: a national organization of nuclear engineers.

2. Chemical Engineers: a national organization of chemical engineers.

3. Science Writers: a national organization of science writers. 
4. Environmentalists: two regional (West coast and East coast) environmental groups and one national environmental group.

5. Hazardous Facility Communities:

residents of $\mathrm{six}$ communities in which potentially hazardous industrial facilities are located.

6. General Communities: residents of six communities chosen without regard to hazardous industrial facilities.

Groups 1, 2, 3 and 4 include established groups. Individual respondents within each of these groups were randomly selected from membership lists. However, the specific groups that were used were not randomly selected from all such groups. Groups 5 and 6 do not consist of established groups. Instead, members of the general public, i.e., residents of the various communities, were treated as though they were members of established groups. Thus, there is no intent in this study to make statements, for example, about the population of communities in which hazardous facilities are located. What is intended are comparisons between the group of respondents 1 iving in Hazardous Facility Communities and the group of respondents living in General Communities, as well as comparisons among these two groups and the other four groups of respondents.

The six communities in the Hazardous Facility Communities group were selected on the basis of geographical diversity and type of hazardous facility: 
1. Red Wing, Minnesota (nuclear power plant)

2. Waterford, Connecticut (nuclear power plant)

3. Everett, Massachusetts (1iquified natural gas terminal)

4. Savannah, Georgia (liquified natural gas terminal)

5. Forsyth/Colstrip, Montana (coal-fired power plant)

6. Pueblo, Colorado (coal-fired power plant)

Selection of the six communities in the General Communities group was based on geographical diversity and size. The six geographic regions in the United States used by Cambridge Reports (see Melber et al., 1977) were adopted in this study; one community was purposively selected from each region:

1. Sạ Francisco (Pacific region)

2. Houston (Central region)

3. Chicago (Midlands region)

4. Detroit (Industrial region)

5. Boston (Northeast region)

6. Atlanta (South region)

Each of the six General Communities is one of the major cities in its geographic region. Large cities were selected on the grounds that a given individual in a large city would be less likely to live close to and be aware of a specific hazardous industrial facility than would a resident of a smaller community in which a major industrial facility is known to exist. For both the Hazardous Facility Communities and the General Communities, individual residents were randomly selected from the local telephone directories. 


\section{Questionnaire Mailing Procedures}

The questionnaire was delivered to all respondents through the use of standard mailing procedures (Dillman, 1978). The questionnaire was 10 pages in length and contained 7 tasks.

The questionnaire mailing procedure consisted of the following steps:

1. Advance notice letter:

Sent to all potential respondents approximately one week before mailing the first questionnaire. Mailed lst class in a bus iness-sized envelope.

2. First mailing of the questionnaire:

The questionnaire, covering letter, and postage-paid business reply envelope were sent to all potential respondents. In an effort to obtain a balanced distribution of male and female respondents in the Hazardous Facility and General Community groups, $50 \%$ of the covering letters contained a request for a male respondent if possible, the remaining $50 \%$ of the letters contained a request for a female respondent. The letters for the other groups of potential respondents contained no reference to sex. The three items were mailed lst class in a $9^{\prime \prime} \times 12^{\prime \prime}$ manila envelope.

3. Second mailing of the questionnaire:

The questionnaire, a new covering letter, and a postage-paid, business reply envelope were sent 1 st class to all potential respondents from whom neither a returned questionnaire nor an indication of non-deliverability was received within 12 days of the first questionnaire mailing. 
4. Third mailing of the questionnaire:

A questionnaire, a new covering letter, and a postage-paid, business reply envelope were sent to all potential respondents from whom neither a returned questionnaire nor an indication of non-deliverability was received within 12 days of the second questionnaire mailing. This final mailing was sent 1 st class, Special Delivery.

5. Response deadline:

The response deadline was three weeks following the third questionnaire mailing.

\section{$\underline{\text { Response Rates }}$}

The response rates for all of the groups were calculated using the procedure 1 isted below (Di11man, 1978).

1. Sent: The number of questionnaires mailed in the first mailing; the gross number of potential respondents.

2. Not Deliverable: The number of questionnaires returned by the Post office due to their inability to locate the addressee.

3. Potential Respondents (Net): The number of potential respondents who presumably received a questionnaire; i.e., the number Sent minus the number Not Deliverable.

4. Acceptable Returns: The number of questionnaires returned that included usable data.

5. Unacceptable Returns: The number of questionnaires returned that did not include usable data.

6. Total Returns: The sum of the Acceptable Returns and the Unacceptable Returns. 
7. Percentage Returned: Total Returns divided by Potential

Respondents. This is the response rate.

The total response rate for all groups was $54 \%$ (see Table 1 ). The response rates for the 6 major groups ranged from $42 \%$ for the General Communities to $92 \%$ for the Nuclear Engineers. These different response rates were not surprising. On the basis of previous studies (e.g., Dillman, 1978; Rankin and Nealey, 1978; Nealey and Rankin, 1978), one would expect that a questionnaire dealing with a specific topic such as nuclear waste management would evoke higher response rates from established groups whose members are known to be interested in that topic than from groups whose members have no known interest in the topic. This pattern of response rates holds true for all of the groups in the study. The General Communities, the Hazardous Facility Communities, and the Science Writers all had response rates around $40 \%$ to $50 \%$. The Science Writers response rate was less than expected. This seemed to be due to lack of time and ethical considerations on the part of the Science Writers (see Earle, 1981). The Environmentalists, the Nuclear Engineers and the Chemical Engineers had response rates from about $80 \%$ to $90 \%$, as expected. The total response rate of $54 \%$ was composed, then, of high response rates and moderate response rates. The lower response rates were associated with lack of specific interest in the central topic of the survey. 
TABLE 1. Response Rates for A11 Groups

\begin{tabular}{|c|c|c|c|}
\hline Name of Group & $\begin{array}{c}\text { Potential } \\
\text { Respondents }\end{array}$ & $\begin{array}{l}\text { Returns, } \\
\text { Total }\end{array}$ & $\begin{array}{l}\text { Percentage } \\
\text { Returned }\end{array}$ \\
\hline \multicolumn{4}{|l|}{ General Communities } \\
\hline San Francisco & 42 & 18 & 43 \\
\hline Houston & 40 & 13 & 33 \\
\hline Chicago & 47 & 18 & 38 \\
\hline Detroit & 55 & 24 & 44 \\
\hline Boston & 47 & 24 & 51 \\
\hline At lanta & 48 & 19 & 40 \\
\hline TOTAL & 279 & 116 & 42 \\
\hline \multicolumn{4}{|l|}{ Hazardous Facility Communities } \\
\hline Red Wing, Minnesota & 47 & 23 & 49 \\
\hline Waterford, Connecticut & 53 & 27 & 51 \\
\hline Everett, Massachusetts & 46 & 21 & 46 \\
\hline Savannah, Georgia & 45 & 19 & 42 \\
\hline Forsyth/Colstrip, Montana & 53 & 20 & 38 \\
\hline Pueblo, Colorado & 46 & 24 & 52 \\
\hline TOTAL & 290 & 134 & 46 \\
\hline \multicolumn{4}{|l|}{ Environmentalists } \\
\hline Western & 24 & 17 & 71 \\
\hline Eastern & 49 & 44 & 90 \\
\hline National & 49 & 37 & 76 \\
\hline TOTAL & 122 & 98 & 80 \\
\hline & & & \\
\hline Nuclear Engineers & 48 & 44 & 92 \\
\hline Chemical Engineers & 48 & 38 & 79 \\
\hline Science Writers & 102 & 51 & 50 \\
\hline GRAND TOTAL & 889 & 481 & 54 \\
\hline
\end{tabular}


PUBLIC CONCERNS ABOUT HIGH-LEVEL WASTE REPOSITORY ISSUES

\section{Introduction}

In order to examine what specific concerns the groups had regarding a high-level waste repository, ten concerns that have been raised by groups involved with nuclear power were presented to the respondents. They were asked to give us their opinion on "...the importance of these issues [to youl compared to other high-level waste management issues." The ratings went from "much less important" (1) through "equally important" (4) to "much more important" (7). In addition, since it was quite possible that some of the respondents were not familiar with one or more of the high-level waste management issues, respondents were given the option of saying "don't know" about issue importance.

The results from this task are presented in Table 2. The average importance ratings for each of the ten waste management issues is. presented for the six groups of respondents and the ranking of issues from most important (1) to least important (10) is given in parentheses. The don't know responses were considered as missing data for these analyses. A few comments will be made on don't know responses before discussing the average importance ratings.

\section{"Don't Know" Responses}

Despite the fact that a don't know response was encouraged if the respondent was not familiar with the issue, this choice was not selected by a large percentage of the respondents. Combining all groups, the don't know response ranged from a low of $4.3 \%$ selection for the two issues involving transportation accidents and accidental digging into the 
TABLE 2. Average Importance of Waste Management Issues Compared to Each Other

\begin{tabular}{|c|c|c|c|c|c|c|c|}
\hline Has te Management Issue & $\begin{array}{c}\text { General } \\
\text { Conmunities } \\
\end{array}$ & $\begin{array}{c}\text { Hazardous } \\
\text { Facility } \\
\text { Communities } \\
\end{array}$ & $\begin{array}{l}\text { Environ- } \\
\text { mentalists }\end{array}$ & $\begin{array}{l}\text { Science } \\
\text { Writers }\end{array}$ & $\begin{array}{l}\text { Chemica 1 } \\
\text { Engineers }\end{array}$ & $\begin{array}{c}\text { Nuclear } \\
\text { Engineers }\end{array}$ & $\mathbf{p}^{\mathbf{b}}$ \\
\hline Transportation accidents & $4.76(7.5)^{a}$ & $4.96(6)$ & $4.94(6)$ & $4.74(3)$ & $4.49(3)$ & $3.72(2)$ & .001 \\
\hline Workers will be harmed & $4.83(6)$ & $5.01(7)$ & $4.41(7)$ & $4.21(6)$ & $3.84(5)$ & $3.30(5)$ & .001 \\
\hline $\begin{array}{l}\text { Leakage of } 1 \text { iquid was tes } \\
\text { from s torage tanks }\end{array}$ & $5.49(1)$ & $5.78(1)$ & $5.69(2)$ & $5.05(2)$ & $4.92(1)$ & $4.88(1)$ & .001 \\
\hline $\begin{array}{l}\text { Explosion from too much } \\
\text { radioactivity }\end{array}$ & $4.93(4)$ & $4.76(8)$ & $4.16(8)$ & $2.56(9)$ & $2.36(8)$ & $1.47(10)$ & .001 \\
\hline $\begin{array}{l}\text { Costs too much and will } \\
\text { raise electricity bills }\end{array}$ & $2.94(10)$ & $3.34(10)$ & $2.57(10)$ & $2.33(10)$ & $1.97(10)$ & $2.09(9)$ & .001 \\
\hline $\begin{array}{l}\text { The permanent disposal containers } \\
\text { for sol id wate will corrode }\end{array}$ & $5.26(3)$ & $5.68(2)$ & $5.52(3)$ & $4.72(4)$ & $4.31(4)$ & 3.24 (6) & .001 \\
\hline $\begin{array}{l}\text { An earthquake may occur and } \\
\text { release materials }\end{array}$ & $4.88(5)$ & $4.77(7)$ & $5.07(5)$ & $3.97(7)$ & $3.61(6)$ & $2.44(7)$ & .001 \\
\hline $\begin{array}{l}\text { Water will get into wastes } \\
\text { and carry radioactivity away }\end{array}$ & $5.30(2)$ & $5.65(3)$ & $5.73(1)$ & $5.29(1)$ & $4.81(2)$ & $3.31(4)$ & .001 \\
\hline Will reduce safety to cut costs & $4.76(7.5)$ & $5.11(4)$ & $5.12(4)$ & $4.41(5)$ & $3.18(3)$ & $3.49(3)$ & .001 \\
\hline $\begin{array}{l}\text { People might accidentally dig } \\
\text { into site }\end{array}$ & $3.88(9)$ & $3.93(9)$ & $3.13(9)$ & $2.87(8)$ & $2.17(9)$ & $2.10(8)$ & .001 \\
\hline
\end{tabular}

NOTE: "For each of the issues, circle one number to give us your opinion on the importance of these issues to you compared to other high-level waste management issues." The numbers ranged from 1 " "much less important" through $4=$ "equally important" to 7 = "much imore important."

a Rank order of issue importance from most important (1) to least important (10) is presented in parentheses.

b The probability that the differences between group means on isaue importance are due to chance alone as determined by analysis of variance. 
repository site to $13.2 \%$ selection for the issue concerning an explosion in the repository. However, the major differences in the selection of don't know responses was among groups, not among issues. For example, in total, only one of the Nuclear Engineers selected the don't know response. In addition, the Chemical Engineers rarely selected the don't know response. Environmentalists and Science Writers selected the don't know response slightly more often--usually about $2 \%$ to $5 \%$ on each issue. However, about $15 \%$ of both samples were unsure about the explosion issue and about $10 \%$ of both samples were unsure about the issue involving cutting safety through cutting cost.

Respondents from the General Communities and Hazardous Facility Communities were most likely to be uncertain about the importance of some of the issues. Typically, from about $10 \%$ to $20 \%$ of both groups were unsure about each of the issues, except for the issue regarding accidentally digging into the site, where on $1 \mathrm{y}$ about $5 \%$ uncertainty was indicated. The greatest amount of uncertainty was found for the explosion issue and for the issue involving high cost raising the electricity bills. In summary, Nuclear Engineers and Chemical Engineers were most familiar with the waste disposal issues and General Communities respondents and Hazardous Facility Communities respondents were least familiar with the issues.

\section{Issue Importance}

Below, the issues are discussed in the order of most important to least important. Importance was determined by averaging across rankings, and is used mostly to provide a method of ordering the discussion of the issues. 
Leakage of 1 iquid wastes. The issue that was generally of most importance was the issue concerning the leakage of liquid wastes from storage tanks. All groups considered this to be the most important issue, except for the Environmentalists and Science Writers, who considered it to be the second most important issue. In terms of significant differences among specific samples, the Nuclear Engineers rated the issue as significantly less important than did the Environmentalists and the Hazardous Facility Communities, and the Chemical Engineers rated the issue as less important than did the Hazardous Facility Communities. None of the other differences among the groups was significant.

The fact that leakage of 1 iquid wastes from storage tanks is seen as the most important high-level waste disposal issue may seem to be a bit puzzling at first, since these storage tanks are being used as an interim measure until final waste disposal can be accomplished. However, there are at least two reasons why this issue is probably believed to be most important. First, the leakage of 1 iquid wastes from storage tanks has occurred in the past and has received extensive media coverage. For example, Rankin et al. (1978) found, in a content analys is of print media coverage of nuclear power issues, that the leak of liquid wastes from tanks on the Hanford Reservation in 1973 was extensively covered by the media and that this leak served as a lead-in for other waste management stories for several years following. In addition, the leakage of liquid wastes at Hanford has been raised in most, if not all, television documentaries on nuclear waste management. Thus, leaky tanks at Hanford are a familiar problem to many members of the public. 
A second reason why this might be seen as the most important waste management issue has to do with relative perceptions of risk from interim storage and from final disposal. That is, it may be the belief of many that the migration of wastes from containment is the most important issue regarding waste disposal, and that this is a more serious problem from just-below-ground tanks, which are close to the biosphere, than are leaks from repositories that are several thousand feet below the earth's surface.

Water carrying wastes away. This second interpretation above is given credence by the fact that the second most important issue for the groups taken as a whole is the concern over water entering the underground repository, which could carry the radioactivity away. This is rated as the most important issue by the Environmentalists and Science Writers, the second most important issue by Chemical Engineers and the General Communities, and the third and fourth most important issues by the Hazardous Facility Communities and the Nuclear Engineers, respectively. The Nuclear Engineers believe this issue to be significantly less of a problem than all other respondent groups, and the Chemical Engineers believe this issue to be less of a problem than the Environmentalists. Otherwise, the remaining groups do not differ significantly between each other on the importance placed on this issue. Corrosion of repository containers. In 1 ine with the major concern being shown over waste migration issues, the issue that was rated third in importance overall is the concern over the corrosion of containers that hold the wastes in the final repository. This concern was rated as the second most important issue by the Hazardous Facility Communities, as 
the third most important issue by the General Communities and by the Environmentalists, as the fourth most important issue by the Science Writers and Chemical Engineers, and as the sixth most important issue by the Nuclear Engineers. The most important point to be made with regard to this issue is the difference in importance placed on this issue between the Nuclear Engineers and all other groups, especially the Environmentalists, the General Communities, and the Hazardous Facility Communities. This may be due to the fact that Nuclear Engineers know that these disposal containers will eventually corrode so that the geologic medium, not the disposal containers, is the most important barrier to the wastes. However, these findings suggest that the other groups place much more importance on the disposal containers as a major barrier to release and that the breaching of this particular barrier is therefore an important concern. The issue takes on even more importance in view of the fact that corrosion of these containers would mean that the wastes would then be more vulnerable to transport by water, which was the second most important issue.

Reducing safety to save costs. The fourth most important issue, averaging across all respondent groups, was a concern over reducing safety in order to cut costs. The major point to be made here is that the Nuclear Engineers 1 isted this as their third major concern. Even so, these respondents did not see this as a major problem, since the average rating was 3.49 .

Transportation accidents. The fifth most important issue, averaged across all groups, was the concern over transportation accidents. The Nuclear Engineers considered this to be the second most important issue, 
the Chemical Engineers and Science Writers rated the issue third in importance, and the other groups rated it sixth or seventh in importance. Again, then, there is a major difference in perceived importance of this issue, especially comparing Nuclear Engineers with the Environmentalists and with the General Communities and the Hazardous Facility Communities.

Workers' safety and earthquakes. The sixth and seventh most important issues were, respectively, concern over the workers' safety and concern over earthquakes occurring and releasing the waste. While group means on issue importance differed somewhat between the groups, the rankings of the issues on importance were fairly consistent across groups.

Explosion. The eighth most important issue, overall, was concern over an explosion in the repository. All groups, except the General Communities, rated this concern as eighth, ninth, or tenth in importance. The General Communities rated this as the fourth most important issue. This is probably due to the fact that many members of the general public equate nuclear materials with nuclear explosions. For instance, over $25 \%$ of the public believes that a nuclear power plant can explode like an atomic bomb (Nealey and Rankin, 1978).

Accidental intrusion and too high a cost. There was general consensus that the remaining two issues were the least important of the ten 1 isted. All respondent groups rated the concern that people would dig into the site and contaminate themselves as eighth or ninth in importance. And, all respondent groups rated the concern that a waste repository would cost too much and would raise their electricity bills as ninth or tenth in importance. 
Absolute level of concern. A final note concerning issue importance deals with the absolute level of concern that the various respondent groups place on a given nuclear waste management issue. If the respondents had answered the question in an ideal manner, the average importance ratings selected across all 10 concerns should have been around 4, which was labelled as "equally important." However, as was expected, the concerns were not rated in an ideal manner, and the range of average responses is in line with our expectations about how the various respondent groups would perceive the overall risk of a nuclear waste facility.

The lowest average rating across all ten concerns was 3.00 , which was the average for the Nuclear Engineers. Thus, as expected, Nuclear Engineers seem to perceive the least risk from a waste facility. The Chemical Engineers had an average concern of 3.57 , which is also less than the ideal average rating of 4 . The Science Writers were next with an average rating of 4.02 , which is an overall "equally important" rating. The remaining three groups exhibited the most concern about the waste issues. The Environmental ists, General Communities, and Hazardous Facility Communities gave average importance ratings, respectively, of 4.63, 4.70, and 4.90. Thus, as expected, the Nuclear Engineers and Chemical Engineers perceived the waste management concerns to be of less importance than did the Environmentalists and respondents from the two types of communities.

\section{Sumnary}

In general, the Nuclear Engineers and Chemical Engineers believed that the waste management issues were of less importance than did the 
other respondent groups, especially the Environmentalists and the respondents from the two conmunity samples. In terms of which issues were believed to be most important and which issues were believed to be least important, there was some concensus across groups. This was analyzed by looking at the issue importance ranking within groups (found by ranking the 10 issues within each group from 1 to 10 and then by comparing the rankings across groups).

Overall, the greatest importance was placed on the issue regarding the leakage of liquid wastes from storage tanks. The Chemical Engineers and the Nuclear Engineers and the two community samples ranked this issue first in importance, while the Science Writers and Environmentalists ranked the issue second in importance.

On the average, the issue that ranked second in importance was regarding water getting into the wastes in the final disposal site and carrying radioactive materials away. The Environmentalists and Science Writers ranked this issue as first in importance, while the other groups ranked it second, third, or fourth. The third most important issue dealt with corrosion of the containers used for final disposal, which was followed closely by concern over transportation accidents.

The least importance was placed on issues dealing with earthquakes releasing radioactive material, radioactive explosions in the repository, accidental digging into the site, and high cost of the repository raising electricity bills.

Finally, it is important to see how Nuclear Engineers issue importance compares with the issue importance of the public and Environmentalists--two groups with which the Nuclear Engineers must 
interact, especially during.the siting phase of the repository. As noted earlier, the most obvious difference is that the Nuclear Engineers did not believe that any of the waste management concerns were as important as the Environmentalists and the community residents. In addition to this difference, the rank order of importance of some of the issues was quite different for the Nuclear Engineers compared with the Environmentalists and the community groups. One of the major differences was regarding the importance of the corrosion of the permanent disposal containers. While the community residents and Environmentalists ranked this as the second or third most important concern, the Nuclear Engineers ranked it as sixth in importance. The low importance placed on this issue by the Nuclear Engineers is probably due to their belief that the main barrier to the escape of radioactivity to the biosphere is the. geologic media, not the disposal containers, which are expected to eventually corrode. However, it is likely that the community residents, especially, believe that the containers are the primary barrier to escape and that corrosion of this barrier is of great concern. This is reinforced by the finding that great importance is placed by these groups on concern over water entering the repository and carrying the radioactivity away.

Another important difference is with regard to the importance placed on explosions in the repository from "too much radioactivity." The Nuclear Engineers are least concerned about this issue, ranking it as last in importance. Environmentalists and Hazardous Facility Communities were also, relatively speaking, not too concerned about this issue, ranking it eighth in importance. However, the General Communities ranked 
this issue as fourth in importance. That is, they seem to be quite concerned about nuclear explosions, even in a repository. Inasmuch as such an explosion is impossible, the waste management information program should try to dispel this concern.

The other issues on which the relative rankings differed between the Nuclear Engineers and the Environmentalists and community residents was transportation of nuclear wastes. The Nuclear Engineers ranked transportation accidents as second in importance, while the Environmentalists, General Communities, and Hazardous Facility Communities ranked it as sixth or seventh in importance. This is likely due to the fact that the Nuclear Engineers believe that much of the risk from waste disposal comes from typical industrial accidents, such as transportation accidents, rather than from issues concerning radioactive contamination. However, the community residents and Environmentalists appear to be much more concerned about radioactivity entering the biosphere than about industrial accidents. 


\section{Introduction}

Another purpose of the questionnaire was to determine whether

respondents believed that low-level repositories and high-level

repositories should be sited on a state, regional, or national basis. Because we were unwilling to assume much knowledge on the part of the respondent regarding low-level and high-level waste, the respondents were first provided with an approximately 400-word summary regarding: a) the difference between low-level and high-level wastes; b) the producers of low-level waste and the fact that all states produce such waste; $c$ ) how low-level wastes are currently disposed; d) the producers of high-level wastes and the number of states involved; and e) how high-level wastes are stored and the likely ultimate disposal process (geologic disposal). Then respondents were asked, separately for low-level waste and for high-level waste, whether they thought that : a) each state should have its own facility for disposing of low-level (high-level) waste;

b) whether six to ten such sites should be chosen on a regional basis; or c) whether two or three such sites should be distributed nationally. If none of these three choices were closest to their belief, they were asked to write in their response.

Low-Level Waste Repositories

The results regarding low-level waste repositories will be presented first (see Table 3 ). There are several important findings to be drawn from these data. First, none of the choices was an overall clear favorite of any of the groups. This can be seen, for example, by the 
TABLE 3. Percentage of Respondents Who Prefer a Given Siting Policy for Low-Level Waste Repositories as a Function

of Respondent Group Membership

\begin{tabular}{|c|c|c|c|c|c|c|}
\hline Responses & $\begin{array}{c}\text { General } \\
\text { Communities }\end{array}$ & $\begin{array}{c}\text { Hazard ous } \\
\text { Facility } \\
\text { Communities } \\
\end{array}$ & $\begin{array}{c}\text { Environ- } \\
\text { mentalists }\end{array}$ & $\begin{array}{l}\text { Science } \\
\text { Writers }\end{array}$ & $\begin{array}{l}\text { Chemical } \\
\text { Engineers }\end{array}$ & $\begin{array}{l}\text { Nuclear } \\
\text { Engineers }\end{array}$ \\
\hline $\begin{array}{l}\text { Each state should have its } \\
\text { own facility. }\end{array}$ & $43.9 \%$ & $39.1 \%$ & $27.3 \%$ & $25.6 \%$ & $37.8 \%$ & $32.6 \%$ \\
\hline $\begin{array}{l}\text { Six to ten sites should be } \\
\text { chosen on a regional basis. }\end{array}$ & 19.4 & 20.9 & 29.5 & 48.7 & 51.4 & 41.9 \\
\hline $\begin{array}{l}\text { Two or three sites should be } \\
\text { distributed nationally. }\end{array}$ & 28.6 & 27.8 & 22.7 & 12.8 & 8.1 & 18.6 \\
\hline Other & 8.2 & 12.2 & 20.5 & 12.8 & 2.7 & 7.0 \\
\hline
\end{tabular}

NOTE: "With regard to the disposal of low-level radioactive wastes, I believe that..." 
fact that majority support was given only to one of the choices (regional siting) by only one group (the Chemical Engineers). Even then, it was only a $51.4 \%$ majority. As another example, the Environmentalists somewhat evenly distributed their choices over the four response categories.

The second important finding deals with the difference between the two community groups and the other four groups regarding the most preferred policy. Whereas the General Communities (44\%) and the Hazardous Facility Communities (39\%) gave fairly strong plurality support to the response that each state should have its own low-level waste disposal facility, the Science Writers (49\%), Chemical Engineers (51\%), and Nuclear Engineers ( $42 \%$ ) gave strong plurality or majority support to the regional siting concept. While more Environmentalists favored the regional siting concept (30\%) compared with the state siting concept $(27 \%)$, the difference was not statistically significant.

A third finding deals with the second most-preferred choice. Both the General Communities and the Hazardous Facility Communities selected the national siting policy (about $28 \%$ ) over the regional siting policy (about 20\%) as the second most preferred policy. However, the Science Writers, Nuclear Engineers, and Chemical Engineers selected the state siting policy (about $25 \%$ to $40 \%$ ) over the national siting policy (about $10 \%$ to $20 \%$ ). The Environmentalists least preferred the national siting plan (23\%).

"Other" responses were provided by a low of $3 \%$ of the Chemical Engineers to a high of $21 \%$ of the Environmentalists. The Engineers and Science Writers tended to offer suggestions regarding siting, and the 
Environmentalists often stated that the wastes should not have been produced in the first place.

The conclusion to be drawn from these data is the obvious one that siting low-level waste repositories is not going to be an easy task. The present-day policy is that each state is responsible for the disposal of low-level radioactive wastes generated in its state. But, in addition, the states have been given the legal authority and encouragement to enter into regional compacts for low-level waste disposal. Thus, the siting policy is more regional in nature, although each state could certainly build its own disposal facility. While the Science Writers, Nuclear Engineers, and Chemical Engineers tend to support the regional siting concept which is currently being pursued by many states, the more "general" public--the General Communities and the Hazardous Facility Communities--tend to support the state siting concept. Additionally, the Environmentalists showed no clear preference for any of the three siting concepts. Thus, while the technical input to the decision process will likely favor the regional concept, the general public is most likely to oppose this concept, believing that each state should have its own low-level waste disposal facility, and the environmentalists are likely to oppose any plan, given their concerns and lack of consensus on any of the siting policies.

\section{High-Level Waste Repositories}

Compared with the lack of consensus regarding the siting of low-level repositories, there was a high degree of consensus on the most preferred high-level repository siting policy (see Table 4). A plurality to majority of all six of the groups selected the national siting policy. 
TABLE 4. Percentage of Respondents Who Prefer a Given Siting

Policy for High-Level Waste Repositories as a Function

of Respondent Group Membership

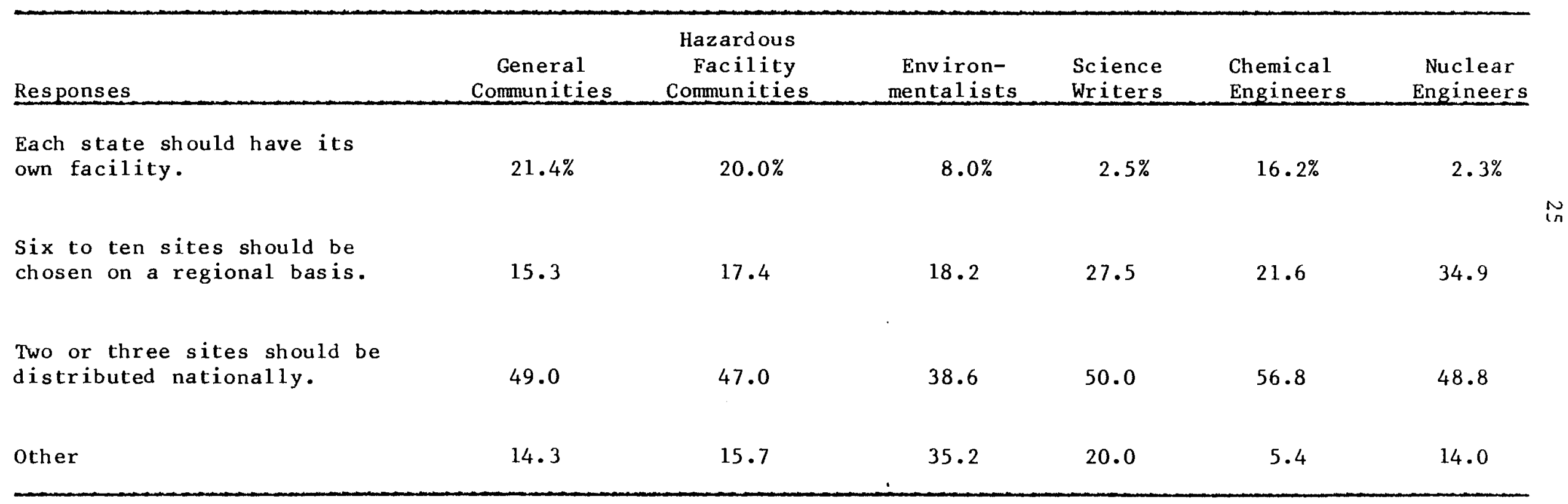

NOTE: "With regard to the disposal of high-level radioactive wastes, I believe that..." 
The most support for the national siting policy was given by the Chemical Engineers (57\%), followed by the Science Writers (50\%), General Communities (49\%), Nuclear Engineers (49\%), Hazardous Facility Communities (47\%), and Environmentalists (39\%). Again, the Environmentalists showed some ambivalence regarding a preference on a siting policy, as indicated by low plurality selection on the national siting policy and by the large percentage (35\%) of "other" responses, which largely dealt with stating that the wastes should not have been produced in the first place.

The other major difference among groups dealt with the second most preferred siting policy for high-leyel waste repositories. The Science Writers (28\%), Nuclear Engineers (35\%), Chemical Engineers (22\%), and Environmentalists (18\%) showed a fairly strong preference for the regional siting concept as a second choice. However, the Hazardous Facility Communities (20\%) and General Communities (21\%) showed a slight preference for the state concept (about 20\%) over the regional concept (about 16\%) for second choice. This seems to indicate a reservoir of feeling that each state should take care of its own wastes, as was strongly indicated in the low-level waste policy choices. Again, the conclusion seems clear that repository siting is going to continue to be a polarized process. All six groups did give plurality to slight majority support to the national siting policy choice. However, the Environmentalists seemed ambivalent about the choices. They possibly chose the national siting policy as the least objectionable of the choices as opposed to selecting it as the most favorable of the choices. In addition, there appears to be strong minority belief among members of 
both types of communities that each state should have its own facility to dispose of high-level wastes. 
This section first summarizes the findings regarding high-level waste repository issue importance. A summary of the low-level and high-level waste repository siting preferences follows. The section ends with a discussion of the relevance of these findings to the Department of Energy (DOE).

Averaged across the six respondent groups, the high-level waste issue regarding the leakage of 1 iquid wastes from storage tanks was seen as most important. There was also general agreement that second in importance was the issue regarding water entering the final repository and carrying radioactive wastes away. Overall, the third most important issue was the corrosion of the metal containers used in the high-level waste repository. However, the General Communities, Hazardous Facility Communities, and the Environmentalists all placed much more importance on this issue than did the Nuclear Engineers, who ranked it sixth.

Overall, the fourth most important issue was reducing repository safety to cut costs. The fifth most important issue was radioactive waste transportation accidents. However, there were large differences among groups in assigning importance to this issue. While the Nuclear Engineers ranked transportation accidents second, the Environmentalists, the General Communities, and the Hazardous Facility Communities ranked the issue sixth or seventh. Overall, the issues ranked sixth and seventh were, respectively, workers' safety and earthquakes damaing the repository and releasing radioactivity.

The eighth most important issue, overall, was regarding explosions in the repository from too much radioactivity. Except for the General 
Communities, all respondent groups ranked this issue eighth through tenth in importance. The General Communities, exhibiting a general concern about nuclear explosions, ranked this issue fourth in importance. There was general agreement across all six respondent groups that the two least important issues involved people accidentally digging into the site and the issue that the repository might cost too much and would therefore raise electricity bills.

There are several important implications to be drawn from these findings. One implication is with regard to the content of information disseminated by waste management information programs. Probably because of previous leaks of 1 iquid wastes from storage tanks, all of the respondent groups are quite concerned about the occurrence of more such leaks. Because the DOE has moved all liquid wastes from the old single wall tanks, which were the type of tanks that had been leaking, into newer double wall tanks, the 1 iquid waste leakage problem has been solved. This fact should be made more widely known to the public through the public information programs. Also, because of major concerns regarding water entering the repository and carrying radioactive materials away, the precautions used to prevent such transport should be clearly spelled out by the information programs. Since the corrosion of waste containers in the repository is a third major concern of the groups and is directly linked to the previous issue, the purpose and intended life of these containers also needs to be spelled out. If nuclear waste technicians do not expect these containers to last a long time, while the respondent groups indicated much concern about the corrosion of these containers, then this issue could gain a lot of importance in the debate 
over the safety of high-level waste repositories. Finally, it is important to note that respondents were quite unconcerned about the issue that the repository might cost too much and would raise electricity bills, but the respondents were concerned that repository safety might be reduced to cut costs. Thus, the point should be made that the repository will have to be built to meet stringent government standards, and that these standards need to be met regardless of cost.

These data also indicate that the nuclear waste technologists involved with waste management do not place the same importance on the waste management issues as do the groups who are likely to oppose a waste repository. If the technologists do not use the information, such as that provided by this study, then they will not likely be properly prepared for meetings with the public. For instance, waste technologists believe, for good technical reasons, that repository explosions are impossible and therefore unimportant, while some members of the public are quite concerned about "atomic explosions." Given this information, waste technologists should be prepared for such concerns, and should be prepared to address the issue as a legitimate concern and not as an "ignorant fear."

The respondent groups were also asked their preferences regarding options for siting low-level and high-level waste repositories. Specifically, they were asked for each type of repository, whether each state should have its own low-level (high-level) repository, whether six to ten sites should be sited on a regional basis, or whether two or three sites should be sited nationally. 
Regarding low-level repositories, Chemical Engineers, Nuclear Engineers, and Science Writers gave plurality to slight majority support to the regional siting option. The second preference for these three groups was the state siting option. However, the General Conmunities and the Hazardous Facility Communities gave plurality preference to the state siting option and second preference to the national siting option. The Environmentalists did not strongly favor any of the three options--each option was chosen $20 \%$ to $30 \%$ of the time as the most preferred option. Slightly more consensus was shown regarding the preferred siting option for high-level waste repositories. All groups gave plurality to majority support to the national siting option. However, the second preference of Nuclear Engineers, Chemical Engineers, and Science Writers was the regional siting option, while the second preference for the General Communities and the Hazardous Facility Communities was the state siting option. Although a plurality of the Environmentalists selected the national siting option, this group again seemed not to favor any of the siting options--over one-third of the Environmentalists offered a different suggestion regarding the siting of high-level waste repositories.

These groups were not asked their policy preferences as a sort of "vote" as to which policy should be implemented. Rather, they were asked their preferences in order to determine how much opposition there might be to the policy options that are now being implemented--the national siting option for high-level waste and the regional siting options for low-level waste. At least two important points can be drawn from the findings . 
First, the more general public (i.e., the General Communities and the Hazardous Facility Communities) has a tendency to believe that each state should have its own radioactive waste disposal facility. This was especially the case for low-level repositories, and, while these groups gave plurality support to the national siting policy for high-level wastes, a large minority still favored the state siting option. Thus, nuclear waste technologists, who must interact with the public, should be prepared to explain why the state siting policy is not the preferred policy, especially for high-level wastes.

Second, the Environmentalists did not strongly favor any of the siting options. Each of the three siting policies for low-level wastes was selected by $20 \%$ to $40 \%$ of this group, with plurality support being given to the state siting option. Also, while about $40 \%$ of the Environmentalists favored the national siting policy for high-level wastes, almost an equal number wrote in another siting preference. Many of those who wrote in a response indicated their belief that the wastes should not have been produced in the first place. While this outlook does nothing to solve the present waste management siting issue, it is indicative of the strong antinuclear feeling among the Environmentalists. Thus, the Environmentalists are unlikely to separate waste management issues from more general questions regarding the growth of nuclear power. Given their lack of strong support for any of the siting options and the importance they place on high-level waste management issues, the Environmentalists are quite likely to oppose any specific siting proposal. 
Babbie, E. R. 1973. Survey research methods. Belmont, CA: Wadsworth.

Blumer, H. 1948. Public opinion and public opinion polling. American Sociological Review, 13(October):542-554.

Dillman, D.A. 1978. Mail and telephone surveys: The total design method. Somerset, NJ: Wiley-Interscience.

Earle, T. C. 1981. Public Perceptions of Industrial Risks: The Context of Public Attitudes Toward Radioactive Waste. Battelle Human Affairs Research Centers, Seattle, WA. BHARC-411-81-002 and PNL-3799.

Glaser, B.G.; and Strauss, A. 1968. The discovery of grounded theory. Chicago: Aldine.

Melber, B.D.; Nealey, S.M.; Hammersla, J.; and Rankin, W.L. 1977. Nuclear Power and the Public: Analys is of Collected Survey Research. Battelle Human Affairs Research Centers, Seattle, WA. $\overline{\text { PNL-2430. }}$

Melber, B.D.; Nealey, S.M.; Weiss, C.S.; and Rankin, W.L. 1979. Nuclear Power and the Public: Update of Collected Survey Research. Battelle Human Affairs Research Centers, Seattle, WA. B-HARC-411-020.

Nealey, S.M.; and Rankin, W.L. 1978. Nuclear Knowledge and Nuclear Attitudes: Is Ignorance Bliss? Battelle Human Affairs Research Centers, Seattle, WA. B-HARC-411-002.

Rankin, W.L.; and Melber, B.D. 1980. Public Perceptions of Nuclear Waste Management Issues. Battelle Human Affairs Research Centers, Seattle, WA. B/HARC-411-80-004.

Rankin, W.L.; and Nealey, S.M. 1978. The Relationship of Human Values and Energey Beliefs to Nuclear Power Attitude. Battelle Human Affairs Research Centers, Seattle, WA. B-HARC-411-007

Rankin, W.L.; Nealey, S.M.; and Montano, D.E. 1978. Analys is of Print Media Coverage of Nuclear Power Issues. Battelle Human Affairs Research Centers, Seattle, WA. B-HARC-411-001.

Willer, D. 1967. Scientific sociology: Theory and method. Englewood Cliffs, NJ: Prentice-Hall. 
No. of

Copies

W. Ballard, Jr.

DOE Office of Energy Programs

Washington, D.C. 20545

D. L. Bodde

Office of Nuclear Policy, Energy Research

Washington, D.C. 20585

A. A. Churm

DOE Chicago Patent Group

9880 South Cass Avenue

Argonne, IL 60439

27 DOE Technical Information Center

P.0. Box 62

Oak Ridge, TN 37830

C. H. George

DOE Office of Waste Isolation

Washington, D.C. 20545

G. Graves

Los Alamos Scientific Laboratory

Los Alamos, NM 87544

J. P. Hamric

DOE Idaho Operations Office

550 2nd Street

Idaho Falls, ID 83401

C. A. Heath

DOE Office of Waste Isolation

Washington, D.C. 20545

D. Jackson

DOE Office of Public Affairs

Albuquerque Operations Office

Albuquerque, NM 87115

C. Jo11y

DOE Office of the Environment

Washington, D.C. 20545
No. of

Copies

M. J. Lawrence

DOE Office of Transportation and Fuel Storage

Washington, D.C. 20545

R. L. Lowrey

Albuquerque Operations Office Box 5400

Albuquerque, NM 87115

J. B, Martin

NRC Division of Fuel Cycle and Material Safety

Washington, D.C. 20555

E. F. Masta1

DOE Office of Resource

Management and Planning

Washington, D.C. 20545

D. F. Miller

DOE Office of Public Affairs

Nevada Operations Office

Las Vegas, NV 89114

R. L. Murray

Nuclear Engineering Department

North Carolina State University

Raleigh, NC 27650

J. O. Neff

DOE National Waste Terminal Storage Program Office

505 King Avenue

Columbus, $\mathrm{OH} \quad 43201$

G. K. Dertel

DOE Office of Waste Operations and Technology

Washington, D.C. 20545 
No. of

Copies

A. F. Perge

DOE Office of the Deputy Assistant Secretary for Nuclear Waste Management Washington, D.C. 20545

J. Pomeroy

National Academy of Sciences

Washington, D.C. 20518

R. W. Ramsey

DOE Projects Staff

Washington, D.C. 20545

L. J. Smith

TRU Waste Systems Office

Rocky Flats Plant

Golden, CO 80401

S. L. Topp

Savannah River Laboratory

Aiken, SC 29801

V. G. Trice

DOE Office of Resource

Management and Planning

Washington, D.C. 20545

E. J. Wahlquist

DOE Office of Resource

Management and Planning

Washington, D.C. 20545

\section{Richland Operations Office}

3 Contract office

T. A. Bauman

P. A. Craig

R. B. Goranson

R. W. Newlin

H. E. Ransom

J. J. Schreiber

M. W. Shupe

F. R. Standerfer

Office of Nuclear Waste Isolation

N. Carter

J. Finley

S. Goldsmith

M. Kehnemuyi

D. Ke1ler

J. Mountain

B. Rawles

J. Marriott
No. of

Copies

Pacific Northwest Laboratory

Technical Files

Publishing Coordination

J. B. Burnham

T. D. Chikalla

D. E. Deonigi

M. R. Kreiter

J. M. Latkovich

R. P. Marshal1

D. E. Olesen

A. M. Platt

J. V. Robinson 